\title{
Measurements of net all-wave radiation at a tropical location, Ile-Ife, Nigeria
}

\author{
MURITALA A. AYOOLA, LUKMAN A. SUNMONU, MUNIRU I. BASHIRU and \\ OLUWAGBEMIGA O. JEGEDE \\ Department of Physics, Obafemi Awolowo University, Ile-Ife, Nigeria \\ Corresponding author: O. O. Jegede; e-mail: oojegede@oauife.edu.ng
}

Received November 28, 2013; accepted June 18, 2014

\begin{abstract}
RESUMEN
Se presentan datos de radiación neta en todas las longitudes de onda promediados cada hora, registrados en una estación meteorológica situada en el campus de la Universidad Obafemi Awolowo, Ile-Ife $\left(7.52^{\circ} \mathrm{N}, 4.52^{\circ} \mathrm{E}\right)$, Nigeria, durante un periodo completo de tres años (2010-2012), para estudiar sus variaciones diurnas y estacionales. Esta información, obtenida con un radiómetro neto de alta sensibilidad de cuatro componentes, representa hasta hoy la información más consistente y detallada disponible para una localidad tropical de África Occidental. De acuerdo con los datos obtenidos, la radiación neta máxima ocurrió a las 14:00 LT (GMT + 1), y sus valores se incrementaron de manera considerable de $337.6 \pm 146.4 \mathrm{Wm}^{-2}$ en julio, que es el pico de la estación lluviosa, a $441.7 \pm 82.4 \mathrm{Wm}^{-2}$ durante marzo, en el final de la estación seca. En los meses de abril y octubre, que marcan el principio y fin de la estación lluviosa en Ile-Ife, se han registrado los valores más altos de radiación neta: 584.7 y $612.2 \mathrm{Wm}^{-2}$, respectivamente. Se observó una importante variación inter e intraestacional en los valores medios mensuales de radiación neta, debida principalmente a fluctuaciones de nubosidad y humedad. En el área de estudio, los datos revelaron la presencia de calentamiento radiativo neto en la superficie, cuya tendencia anual sigue una distribución bimodal. Los datos de este estudio respaldan los aportados por otros autores.
\end{abstract}

\begin{abstract}
Hourly averaged net all-wave radiation data spanning a complete three-year period (2010-2012) at a meteorological station located inside the Obafemi Awolowo University campus in Ile-Ife $\left(7.52^{\circ} \mathrm{N}, 4.52^{\circ} \mathrm{E}\right)$, Nigeria is presented in this study to investigate its diurnal and seasonal variations. Using a high-sensitivity four-component net radiometer, the data represents so far the most consistent and detailed information available for a tropical location in West Africa. From the dataset, hourly maxima of the net radiation occurred at 14:00 LT (GMT + 1), whose values increased considerably from $337.6 \pm 146.4 \mathrm{Wm}^{-2}$ in July, which is the peak of the wet season, to $441.7 \pm 82.4 \mathrm{Wm}^{-2}$ in March, the end of the dry season. April and October, both of which mark the beginning and end of the raining season at Ile-Ife have recorded the highest values of 584.7 and $612.2 \mathrm{Wm}^{-2}$, respectively. There was strong intra/inter-seasonal variation observed in the monthly mean values of the net radiation due mainly to the fluctuations in cloudiness and humidity. In the study area, the data indicated a net radiative heating taking place at the surface, whose annual trend follows a bimodal distribution. The present data supports the results published in earlier studies by other authors.
\end{abstract}

Keywords: Tropical wet and dry; Ile-Ife, Nigeria, net radiation; bare soil, intra/inter-seasonal variations, radiative heating.

\section{Introduction}

The importance of reliable and continuous measurements of net all-wave radiation at the land surface cannot be overemphasized for fundamental research and applications in meteorology, as it determines the total amount of energy available for physical and biological processes such as evapotranspiration, air and soil warming. Particularly, net radiation data is 
required for modeling mass and energy exchange processes between the atmosphere and land surface (Arya, 1988; Iziomon et al., 2000; Foken 2008a).

Net all-wave radiation at the surface can be determined as the algebraic sum of incoming and outgoing solar (shortwave, 0.15-4 $\mu \mathrm{m}$ ) and atmospheric (longwave, 3-100 $\mu \mathrm{m}$ ) radiation, which is expressed symbolically as:

$R_{N}=R_{S} \downarrow+R_{S} \uparrow+R_{L} \uparrow+R_{L} \downarrow$

where $R_{N}$ is the net (all-wave) radiation, $R_{S} \downarrow$ is the in-coming shortwave (or solar) radiation, $R_{S} \uparrow$ is the out- going (reflected) shortwave radiation, $R_{L} \uparrow$ is theincoming long-wave(sky)radiationand $R_{L} \downarrow$ is theoutgoing (terrestrial) longwave radiation. $R_{S} \downarrow$ is calculated from the sum of the horizontal beam and diffuse solar radiation (termed global radiation). The outgoing shortwave radiation $R_{S} \uparrow$ is determined as the fraction of incoming radiation, which is reflected by the surface, that is,

$R_{S} \uparrow=a R_{\mathrm{S}} \downarrow$

where $a$ is the surface reflection coefficient, which is termed albedo. Values of this parameter depend on the surface cover type, color, textural characteristics and wetness degree. Typically, for vegetative surfaces the value is between 0.16 for long grass and 0.25 for agricultural lands. Over bare soil surfaces, the range is between 0.05 for wet fallow field and 0.45 for dry sand (Arnfield, 1975; Arya, 1988).

The outgoing (terrestrial) longwave radiation, $R_{L} \uparrow$ is given as a function of the fourth power of the surface temperature (the Stefan-Boltzmann's law). As such, $R_{L} \uparrow$ shows a strong diurnal variation over most natural surfaces. Of the incoming longwave radiation, $R_{L} \downarrow$ is found to be dependent primarily on temperature inhomogeneities in the boundary layer because of the high concentrations of water vapor and carbon dioxide, both of which are strong emitters of infrared (thermal) radiation (Viudez-Mora, 2011). Both longwave radiation components, $R_{L} \uparrow$ and $R_{L} \downarrow$, are nearly of the same magnitude; hence the values of longwave radiation balance at the surface are usually small (Smith and Rutan, 2003).

Net all-wave radiation $R_{N}$ measured at the surface, which is given by Eq. (1.), has distinctly contrasting values for daytime and nighttime conditions due to the absence/presence of solar radiation. In sub-tropical areas, due to the high intensity of incoming solar radiation (which is about $1000 \mathrm{Wm}^{-2}$ at the local noon), the ratio of net longwave radiation $\left(R_{L}=R_{L} \downarrow\right.$ $\left.+R_{L} \uparrow\right)$ to net shortwave radiation $\left(R_{S}=R_{S} \downarrow+R_{S} \uparrow\right)$, which depends on the degree of cloudiness, is roughly about 0.05 to 0.2 (Jegede, 1997a; Alados et al., 2003; Matuszko, 2012). At nighttime, due to the absence of insolation, the terms representing shortwave radiation are absent, so that $R_{S}=0$. Therefore,

$R_{N}= \begin{cases}\{0.80 \sim 0.95\} R_{S} & (\text { Daytime }) \\ R_{L} & (\text { Nightime })\end{cases}$

The measured net radiation is dependent on geographical location, time of the day, season, cloudiness, surface temperature, and type and conditions of the surface as indicated by albedo and emissivity (Augustine and Dutton, 2013; Matzinger et al., 2003). Due to the fleeting nature of convective clouds and the highly humid conditions commonly occurring in tropical areas, there is a preponderance of the short-period ( $<1 \mathrm{~min}$ ) fluctuations superimposed on the mean net radiation (Jegede et al., 2006; Kothe and Ahrens, 2010). There are several empirical relationships that can be used to estimate net radiation from routinely measured meteorological data including air temperature, insolation, cloudiness and relative humidity (e.g. Nielsen et al., 1981; Amarakoon and Chen, 1999). A major disadvantage is that these empirical relationships are not accurate enough for sensitivity tests in the modeling of surface energy exchange processes (Alados et al., 2003).

In the present study, continuous measurements of hourly-averaged net radiation data for Ile-Ife $\left(7.52^{\circ} \mathrm{N}\right.$ latitude, $4.52^{\circ} \mathrm{E}$ longitude), Nigeria by a four-component net radiometer (model NR01) recorded over a period of three years (2010-2012) have been utilized for investigating temporal variations at a particular site located in a tropical area.

\section{Net radiation at low latitudes in West Africa}

In continental areas of West Africa below $15^{\circ} \mathrm{N}$ latitude, the sun is always high up in the sky at the local noon. The seasonal weather pattern is determined primarily by the latitudinal position of the inter-tropical discontinuity (ITD) line. The ITD line is where the moist southwesterly current, which originates 
in the Atlantic Ocean, and the dusty northeasterly winds coming from the Sahara desert (Adejokun, 1966) meet at the surface. The north-south (transverse) movement of the ITD line over West Africa is associated with distinct weather seasons within the sub-continent, namely the wet and dry seasons. Near the $7^{\circ} \mathrm{N}$ latitude both seasons are almost of equal duration throughout the year .

Despite relatively simple instrumentation for measuring net radiation at the land surface, the data is still scarce for most parts of West Africa (Jegede, 1997a, b, c, 2003). The few net radiation datasets available for the region are collated from major field experiments such as the HAPEX-Sahel conducted in the West African Sahel (Goutourbe et al., 1994). Availability of satellite derived net radiation data promises to complement the paucity of these measurements, even though such data does not have the spatial or temporal resolution that in situ net radiation sensors provide. The maintenance of net radiation measurements on a continuous long-time basis is expensive, so it is usually estimated (Nielsen et al., 1981).

Analysis of net radiation data over continental West Africa by Ojo (1977) indicates a pattern of latitudinal variation such that there is an increase from coastal to inland areas throughout the year. In coastal areas - the latitudinal belt between $4^{\circ}$ and $6^{\circ} \mathrm{N}$ - daily mean values of net radiation reported for January are about $80 \mathrm{Wm}^{-2}$, and they increase to $125 \mathrm{Wm}^{-2}$ at about $16^{\circ} \mathrm{N}$ latitude. Due to increased cloudiness in July, the daily averages of the net radiation obtained were considerably lower, but the spatial patterns were similar. In a reanalysis by Hayward and Oguntoyinbo (1987), spatial and temporal variations of the net radiation over West Africa correlate strongly with cloudiness and humidity. This observation supports the fact that the combined effects of cloudiness and a high mixing ratio are responsible for the lowering of net radiation values during the wet (monsoon) season (Kothe and Ahrens, 2010).

In West Africa, daily averages of hourly net radiation vary considerably between seasons. Hourly net radiation data obtained for Osu $\left(7.43^{\circ} \mathrm{N}, 4.58^{\circ} \mathrm{E}\right)$, Nigeria in 1995 and published by Jegede (1997a, b, c) indicated a period average during the wet season (typically, April-October) of $382 \pm 136.7 \mathrm{Wm}^{-2}$, whereas this average was of $480.3 \pm 61.8 \mathrm{Wm}^{-2}$ for the dry season (November-March). The peak hourly data at 14:00 LT $($ GMT + 1) showed a bi- modal pattern with values of 436.4 and $520.3 \mathrm{Wm}^{-2}$ recorded in March and November, respectively. In the same study, the lowest value for the hourly maxima of net radiation $\left(307.7 \mathrm{Wm}^{-2}\right)$ was recorded in July, which is the peak of the wet season at Osu. This result was attributed to the frequent occurrences of convective clouds during the month. This seasonal pattern of net radiation values is in agreement with earlier studies by Ojo (1977) and Hayward and Oguntoyinbo (1987).

\section{Methodology}

Figure 1 shows the location of Ile-Ife $\left(7.52^{\circ} \mathrm{N}, 4.52^{\circ} \mathrm{E}\right)$, Nigeria in the "tropical wet and dry" zone of West Africa according to the Köppen's classification (Griffiths, 1974). Average annual precipitation ranges from 1000 to $1500 \mathrm{~mm}$, and surface wind typically is weak, with a mean speed lower than $1.5 \mathrm{~ms}^{-1}$ (Hayward and Oguntoyinbo, 1987; Jegede, 1998). Due to its proximity to the equator, the intensity of solar radiation received at Ile-Ife's surface is high all year round. From the hourly global radiation data at Ile-Ife, maxima is found at about 13:00 LT, with values of 1100 and $800 \mathrm{Wm}^{-2}$ for March and August, respectively (Balogun et al., 2003).

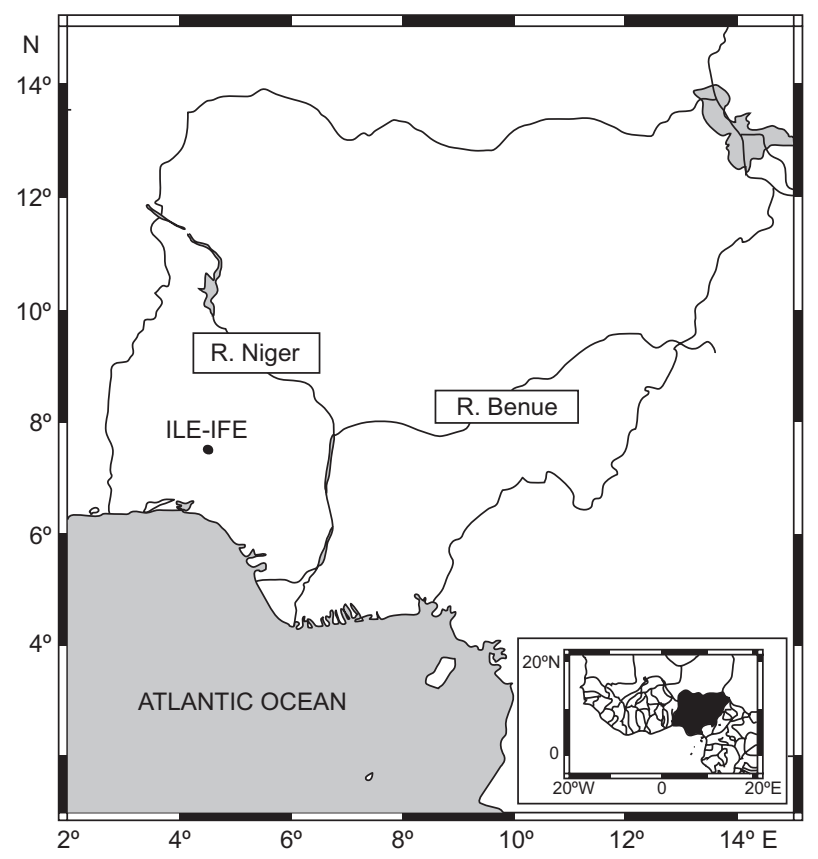

Fig. 1. Outline map of Nigeria showing the location of IleIfe $\left(7.52^{\circ} \mathrm{N}, 4.52^{\circ} \mathrm{E}\right)$, where the net radiation measurement (2010-2012) was recorded. Insert is the sub-continent of West Africa. 
A net radiometer was used to perform measurements of net radiation at the surface. Basically, there are two designs for net radiometer sensors: a double-dome radiometer that measures integrated all-wave $(0.25-60 \mu \mathrm{m})$ radiation or a four-component device that measures individual components of the shortwave and longwave radiation (Duchon and Wilk, 1994). An example of the first type is the radiation energy balance systems (REBS). Improvements both in the design and the materials for such net radiometers allow for a systematic error of less than $10 \%$ of absolute values (Halldin and Lindroth, 1992; Foken, 2008b). Measurements by the four-component net radiometers have better accuracy than REBS, especially at nighttime, when the magnitude of $R_{N}$ is low $\left(<20 \mathrm{Wm}^{-2}\right)$ (Foken, 2008b).

Net radiation data is presently being acquired at a meteorological station in the Obafemi Awolowo University campus (Fig. 2), Ile-Ife $\left(7.52^{\circ} \mathrm{N}, 4.52^{\circ} \mathrm{E}\right)$, Nigeria among many other meteorological variables, as part of the Nigeria Micrometeorological Experiment (NIMEX). Time series of the basic meteorological parameters are collected routinely on a continual basis at the measurement site located near the Department of Physics building. The surface cover of the measurement site is bare soil (the top soil is sandy clay) and the enclosure has an area of $11 \times 11 \mathrm{~m}$. In the surroundings of the measurement surface there is a low vegetation cover and in the far distance office buildings and tall trees obstruct the free flow of air to the measurement area.
In the middle of the measurement area stands a $6 \mathrm{~m}$ mast supported by guy-wires, with meteorological sensors hanging from booms, such as cup anemometers, a wind-vane, a temperature and humidity sensor, and a REBS net radiometer (NR-LITE, manufactured by Kipp \& Zonen B.V., Netherlands). Soil heat flux plates and thermistor soil temperature probes are buried in the ground at 5, 10, and $30 \mathrm{~cm}$; and at 2, 5, 10, and $30 \mathrm{~cm}$ depths, respectively. A tipping bucket-type rain gauge was co-located at the station. All of these devices were connected to a dedicated datalogger (model CR10X, Campbell Scientific Instruments).

A four-component net radiometer (model NR01) was placed on a separate mast $1.3 \mathrm{~m}$ above the ground. This device consists of two pyranometers (model SR01) and two pyrgeometers (model IR01), both of which are back-facing, to measure the upwelling and downwelling shortwave and longwave radiation, respectively. All sensors have individual calibration factors. The sensitivities for the top and bottom pyranometers were specified as 15.74 and $15.60 \mu \mathrm{V} / \mathrm{Wm}^{-2}$, respectively. For the IR01 pyrgeometers sensitivities were specified as 9.90 and $8.20 \mu \mathrm{V} / \mathrm{Wm}^{-2}$ for the top and bottom sensors, respectively. The response time of the radiation sensors was less than $18 \mathrm{~s}$. The NR01 sensor was bought in 2009 brand-new with the calibration certificate provided by the manufacturer (Hukseflux Thermal Sensors B.V., Netherlands). The instrument calibration procedure in accordance to the World Radiometric Reference (WRR) is traceable to ISO 9847. The NR01

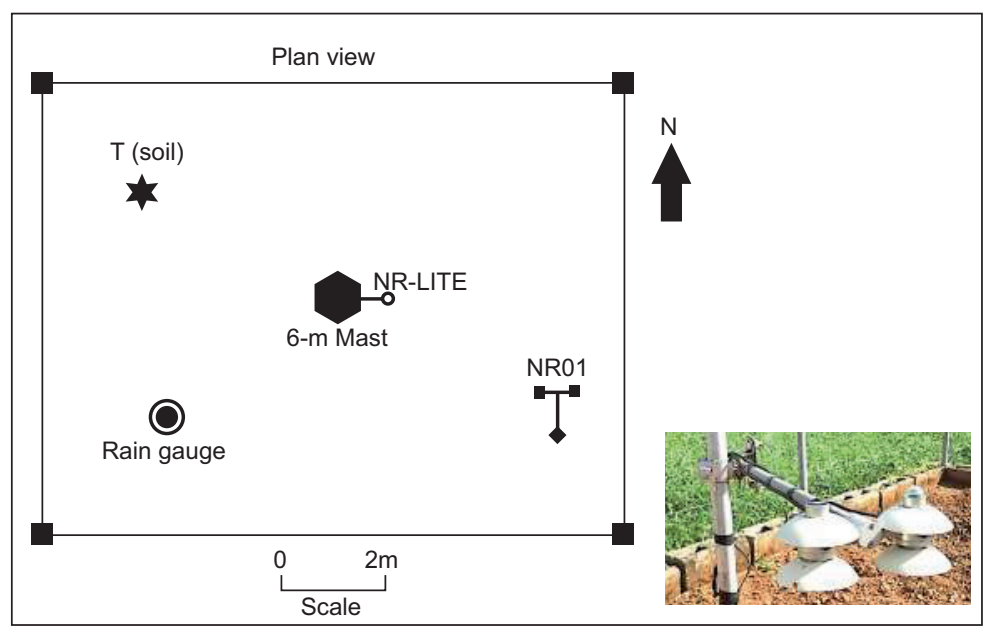

Fig. 2. Plan view of sensors at the meteorological station, Obafemi Awolowo University (OAU), Ile-Ife, Nigeria. Shown in the insert is the four-component net radiometer (model NR01). 
net radiometer was connected to a second CR10X datalogger using differential input channels for the voltage measurements to achieve better accuracy.

Data acquisition by the NR01 was programmed using the LoggerNet ${ }^{\circledR}$ software supplied by Campbell Scientific. The raw data were sampled at $10 \mathrm{~s}$ intervals and the time series stored as 2-min averages. For data consistency, net radiation acquired by NR01 was compared to the measurements made by the NR-LITE. All the net radiation 2-min averages were carefully checked for instrumental errors and out-range values. Stringent QA/QC procedure was introduced to remove spurious data and replace missing values. The net radiation measurements acquired for this study covered the period from January 2010 to December 2012.

\section{Discussion}

The diurnal variation of net radiation at Ile-Ife, Nigeria from January to December, for 2010, 2011 and 2012, is shown in Figure 3a, b, c, respectively. Hourly averages of net radiation, together with the corresponding values of the standard deviation (SD) are plotted in this figure. In accordance with the sign convention chosen, the positive values of $R_{N}$ are indicative of radiative heating occurring at the surface, while the converse holds true for negative values (i.e. radiative cooling). At this location, from midnight to about 07:00 LT (GMT +1$)$, values of net radiation are negative and fairly constant. The measured values are found to be within -50 and $-20 \mathrm{Wm}^{-2}$, thus indicating radiative cooling at the surface during this period. Beyond 07:00 LT the net radiation is positive and the values increase monotonically as the sun rises overhead until about 14:00 LT, when it reaches the local maxima. Later, as the sun is setting, the magnitude of net radiation drops steadily until about 19:00 LT, when its sign changes again to negative values. At the studied
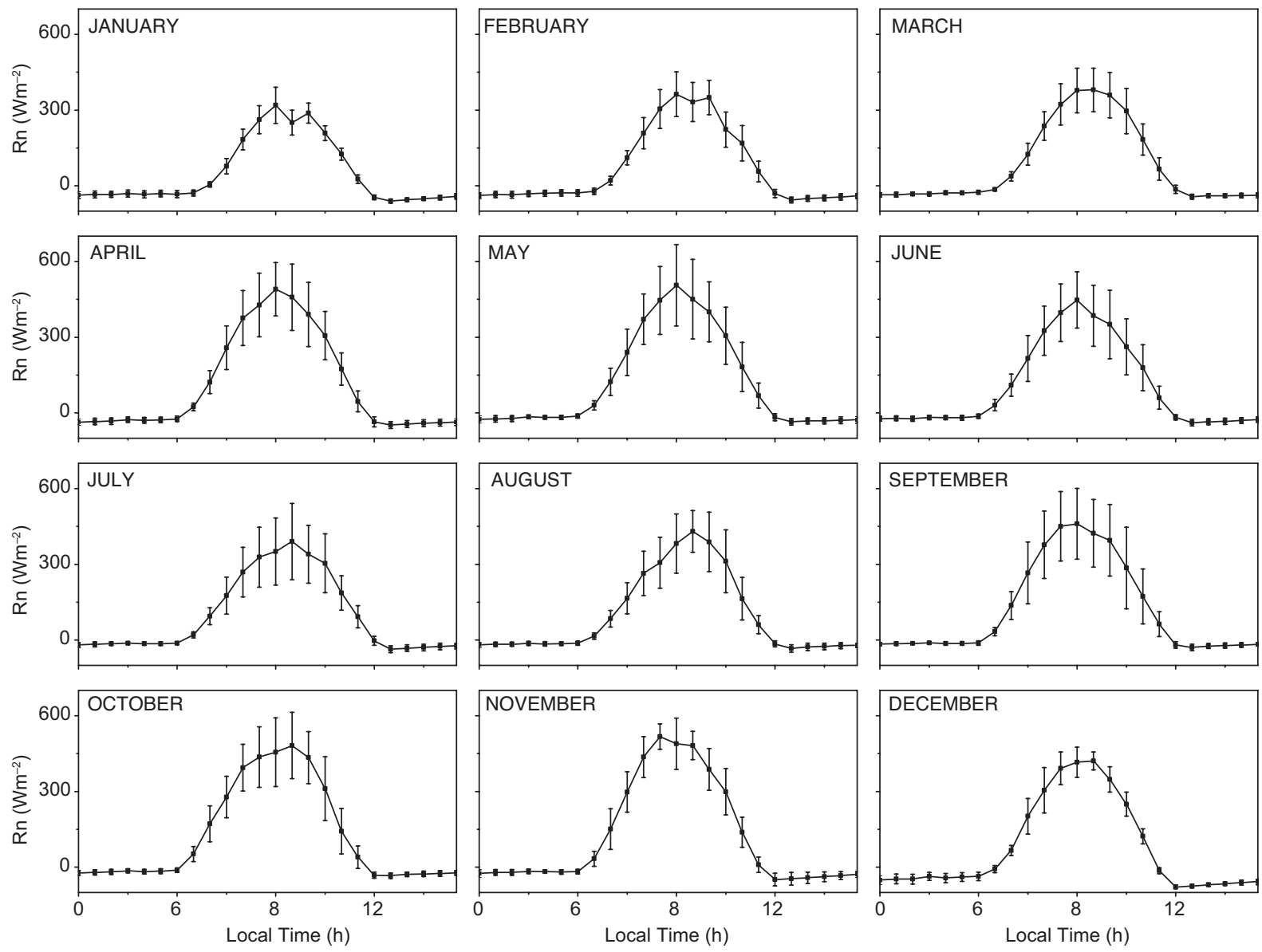

Fig. 3. (a) Diurnal variation of net radiation at the OAU measurement site for the period January-December, 2010. 
2011
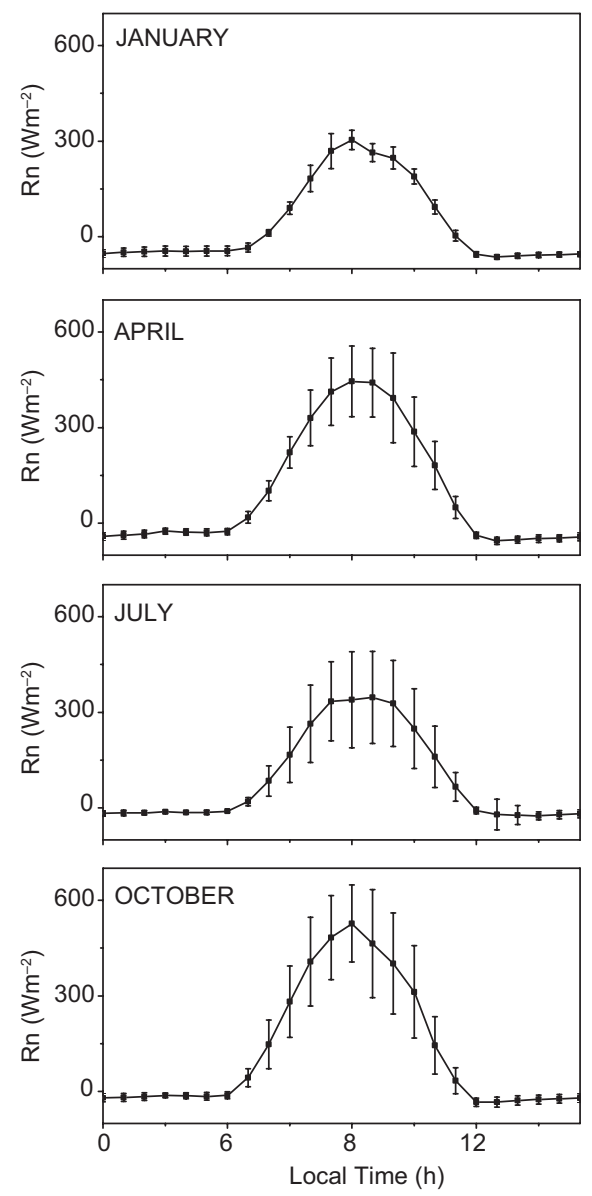
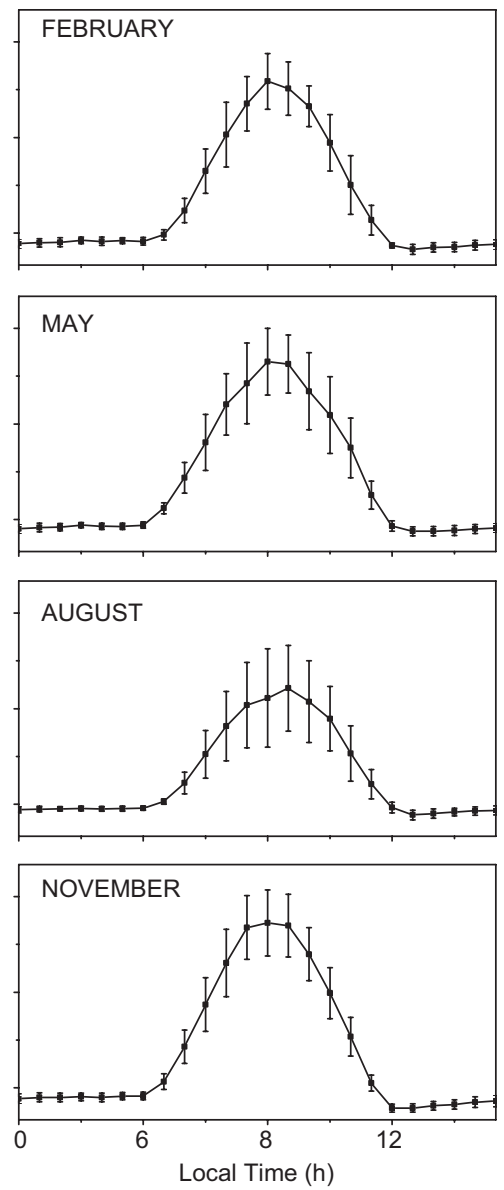
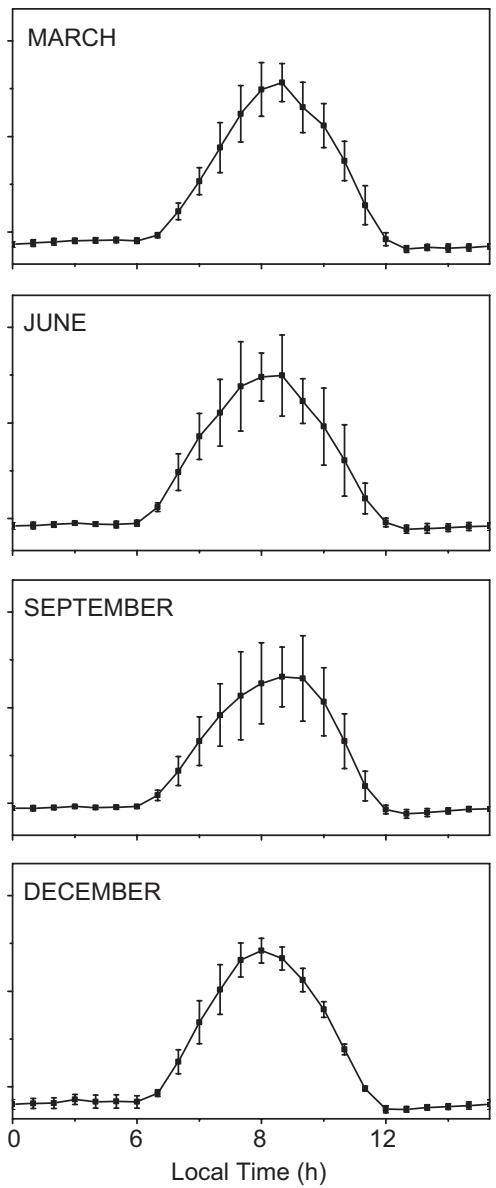

Fig. 3. (b) Same as (a), but for the period January-December, 2011.

location $\left(7.52^{\circ} \mathrm{N}\right)$, sunrise and sunset times are approximately 07:00 and 19:00 LT, respectively.

The magnitude of the maxima for the hourly averaged net radiation values (Figure 3) from January to December (2010-2012) was observed to vary in accordance with the change of dry to wet season (November-March and April-October, respectively) at Ile-Ife. For instance, in January, which is the peak of the dry season in the area, highly turbid atmospheric conditions (arising from dusty spells of wind-blown aeolian aerosols of Saharan origin, known locally as harmattan) result in low values of daytime net radiation. The net radiation value at 14:00 LT for January was $331.6 \pm 54.3 \mathrm{Wm}^{-2}$, which evidently was the lowest of the year. The following months, February and March are transitional between dry and wet season, with occasional showers leading to marked reduction in turbidity. Consequently, net radiation maxima at the location for both months increased considerably to $417.1 \pm 91.3 \mathrm{Wm}^{-2}$ and $441.7 \pm 82.4 \mathrm{Wm}^{-2}$. In April and May, when the wet (rainy) season was well established at the location, the maximum daytime net radiation values increased to $454.4 \pm 122.3 \mathrm{Wm}^{-2}$ and $460.7 \pm 134.8 \mathrm{Wm}^{-2}$, respectively. At the peak of the wet season in July-August, due to frequent thunderstorm activities that accompany the formation of cumulonimbus clouds (Cbs), the lowest amounts reported were $337.6 \pm 146.7 \mathrm{Wm}^{-2}$ and $339.7 \pm 118.2 \mathrm{Wm}^{-2}$, respectively. It is remarkable that the tendency and range of values of net radiation in Ile-Ife are in good agreement to the measurements reported earlier by Jegede (1997b, c, 2003) at Osu, a nearby location.

Figure 4 shows hourly average values for net radiation during the whole year and the wet and dry seasons at the measurement site during the period of observation (2010-2012). It can be observed from Figure 4 that the fluctuation (SD) of net radiation is up to $150 \mathrm{Wm}^{-2}$ in the daytime during the wet season. 
2012
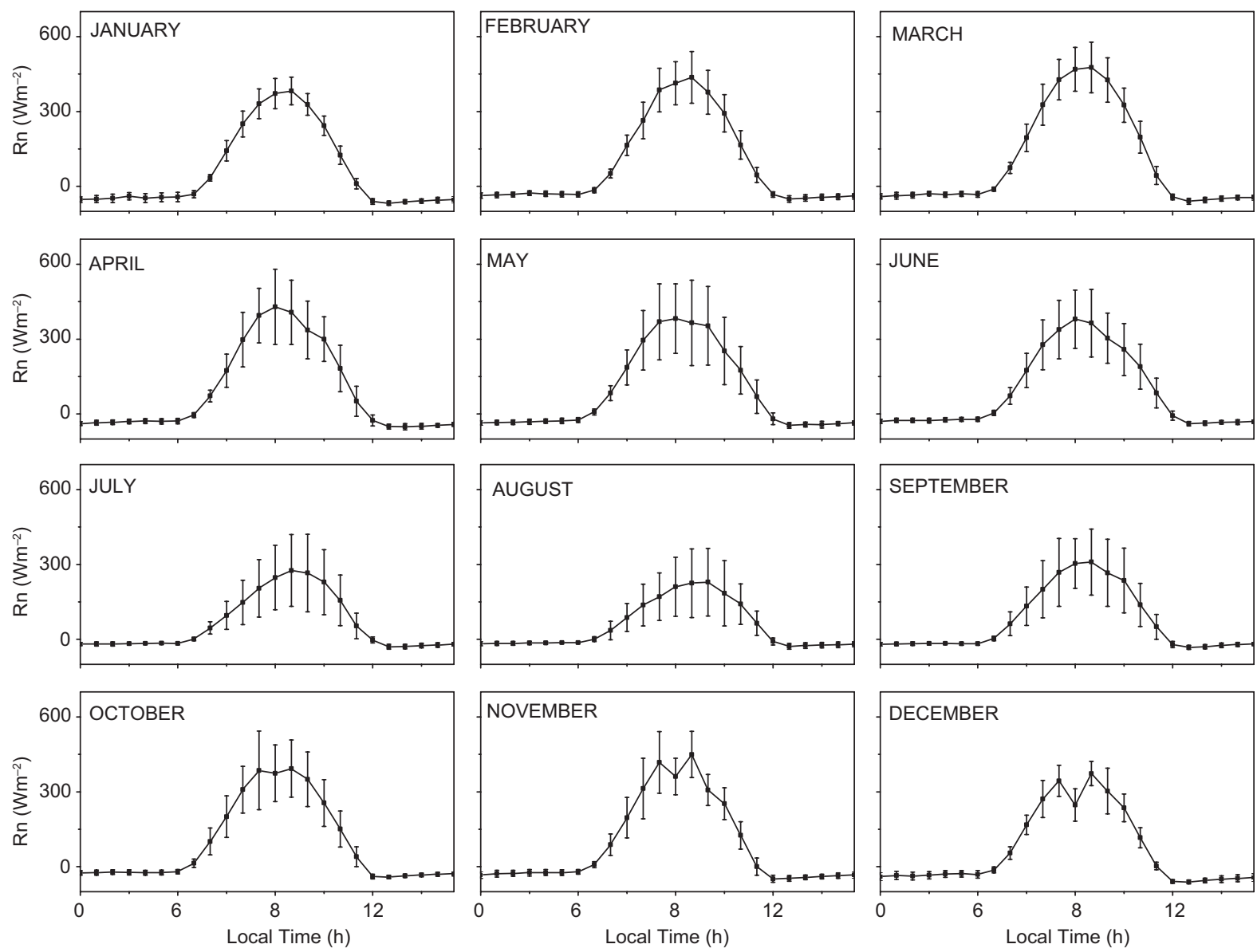

Fig. 3. (c) Same as (a), but for the period January-December, 2012.

In the dry season, shown also in Figure 4, fluctuation is lower than $100 \mathrm{Wm}^{-2}$. Though hourly averaged values of net radiation during the wet season are lower than in the dry months, the larger fluctuations can be attributed to frequently occurring cloudy conditions (Jegede et al., 2006). In daytime periods, the difference between hourly-averaged values of net radiation in the dry and wet seasons falls between 0 and 20 $\mathrm{Wm}^{-2}$. However, at sunrise and sunset, a difference of up to $35 \mathrm{Wm}^{-2}$ was observed. Generally, the hourly averaged values of net radiation for the wet season are higher except between 11:00 and 14:00 L.T., when a reversal was observed. This feature is most probably due to the increased cloudiness during these hours, thereby resulting in reduced values of net radiation in the wet season. From the annual average of net radiation (shown in Fig. 4c), daytime (08:00-18:00 LT) values ranged between $45.8 \pm 39.8 \mathrm{Wm}^{-2}$ and $400.9 \pm 104.4 \mathrm{Wm}^{-2}$. For nighttime periods (20:00-
06:00 LT), the corresponding values ranged between $-40.9 \pm 11.7 \mathrm{Wm}^{-2}$ and $-22.2 \pm 10.0 \mathrm{Wm}^{-2}$. Table I shows the hourly averaged values of net radiation $\left(R_{N}\right)$ at Ile-Ife for the period 2010-2012, which indicate that maximum net radiation occurs at about 13:00 LT (GMT + 1) and reaches peak values of about $400 \mathrm{Wm}^{-2}$; the corresponding SD value is about 72 $\mathrm{Wm}^{-2}$ for the observation period (2010-2012).

Fluctuation of the diurnal trend of net radiation is very pronounced during the wet (monsoon) season, as shown in Figure 4. The intermittency of incoming solar radiation is attributable mainly to the transient nature of convective clouds, which arise due to intense surface heating from the late morning hours (Adejokun, 1966). However, during the dry season, the thermodynamic structure of lower troposphere inhibits the development and growth of convective clouds, hence a lower fluctuation of hourly averages of net radiation is recorded. 

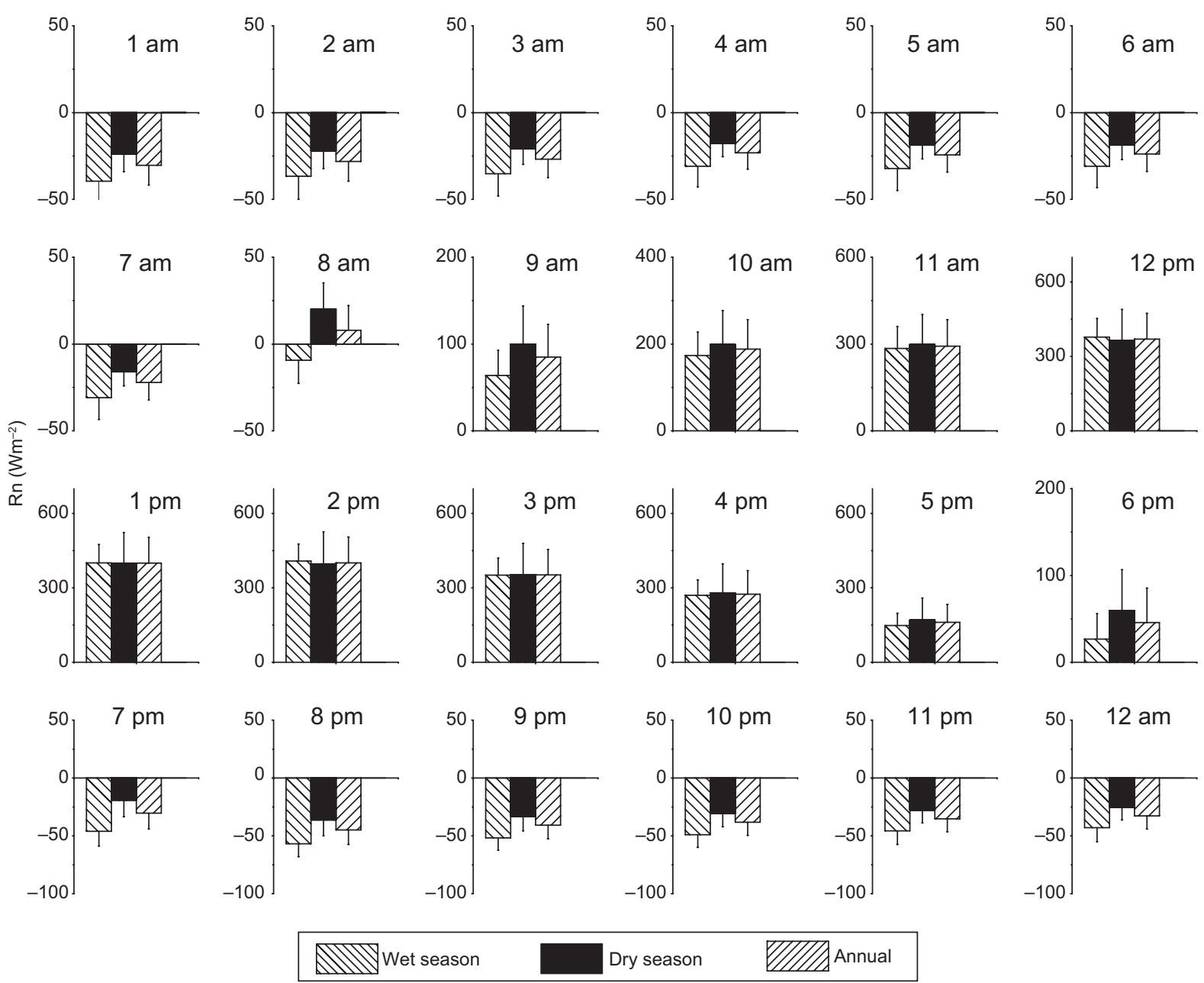

Fig. 4. Hourly average values of net radiation at the OAU measurement site in Ile-Ife, Nigeria for the whole year and for the wet and dry seasons, covering the period of observation 2010-2012.

"Box and whisker" plots of hourly averaged values of net radiation for January to December at the study site are presented in Figure 5, whose statistical distribution contains the following scores: quartiles (25th and 75th percentiles), median (50th percentile), mean, minimum and maximum values. From the box plots for April and October, both of which mark the beginning and end of the raining season at Ile-Ife, the highest hourly averaged values of net radiation are reported to be 584.7 and $612.2 \mathrm{Wm}^{-2}$, respectively. Similarly, the interquartile range (25th-75th) for April and October was found to be the largest.

From the monthly means of net radiation, October also recorded the highest value $\left(112.4 \mathrm{Wm}^{-2}\right)$, while the lowest value $\left(50.7 \mathrm{Wm}^{-2}\right)$ was found in January. At the peak of the rainy season (July-August) the monthly mean values of net radiation were 82.3 and $78.4 \mathrm{Wm}^{-2}$, respectively. The low value of net radiation reported in July-August is due to cloudy conditions during the daytime. The observed trend of monthly mean values of net radiation in West Africa, which is bimodal, is in agreement with findings by Ojo (1977), Hayward and Oguntoyinbo (1987) and Jegede (1997a, b, c).

The monthly mean values of net radiation have been used to investigate whether there was a net radiative cooling or heating at the surface of the study site. The monthly averaged values of net radiation shown in Figure 6 indicate that throughout the year there was cooling at the surface in nighttimes/early mornings (19:00-07:00 LT), but there was a consistent heating of larger magnitude during daytime (08:00-18:00 LT). In May and October the largest recorded values of net radiative heating at the surface 
Table I. Diurnal variation of net radiation, $\mathrm{R}_{\mathrm{N}}\left(\right.$ in $\left.\mathrm{Wm}^{-2}\right)$ at Ile-Ife $\left(7.52^{\circ} \mathrm{N}\right.$, $\left.4.52^{\circ} \mathrm{E}\right)$, Nigeria for the period 2010-2012.

\begin{tabular}{crrrr}
\hline \multirow{2}{*}{ Local time* } & 2010 & 2011 & 2012 & \multicolumn{2}{c}{ Period average } \\
& $R_{N}$ & \multicolumn{1}{c}{$R_{N}$} & \multicolumn{1}{c}{$R_{N}$} & \multicolumn{1}{c}{$R_{N}$} \\
\hline 0 & $-28.6 \pm 10.7$ & $-30.9 \pm 13.3$ & $-31.9 \pm 10.5$ & -30.5 \\
1 & $-26.3 \pm 9.9$ & $-28.6 \pm 12.5$ & $-29.6 \pm 9.9$ & -28.2 \\
2 & $-25.6 \pm 10.4$ & $-26.6 \pm 12.6$ & $-28.6 \pm 9.4$ & -26.9 \\
3 & $-21.4 \pm 9.1$ & $-22.2 \pm 11.2$ & $-25.9 \pm 7.5$ & -23.2 \\
4 & $-22.8 \pm 9.3$ & $-24.4 \pm 11.7$ & $-26.0 \pm 8.8$ & -24.4 \\
5 & $-22.1 \pm 8.1$ & $-23.9 \pm 11.2$ & $-25.4 \pm 8.2$ & -23.8 \\
6 & $-19.7 \pm 9.2$ & $-22.5 \pm 12.6$ & $-24.7 \pm 8.5$ & -22.3 \\
7 & $14.2 \pm 25.6$ & $11.5 \pm 23.9$ & $-2.8 \pm 12.8$ & 7.6 \\
8 & $93.9 \pm 52.5$ & $94.6 \pm 39.7$ & $64.7 \pm 21.0$ & 84.4 \\
9 & $201.2 \pm 70.9$ & $202.5 \pm 54.5$ & $159.8 \pm 37.8$ & 187.8 \\
10 & $312.1 \pm 80.5$ & $305.8 \pm 64.1$ & $257.5 \pm 63.3$ & 291.8 \\
11 & $382.4 \pm 76.8$ & $388.7 \pm 68.2$ & $336.4 \pm 81.8$ & 369.2 \\
12 & $421.1 \pm 61.8$ & $427.5 \pm 74.1$ & $349.1 \pm 79.8$ & 399.2 \\
13 & $406.9 \pm 66.3$ & $420.4 \pm 69.3$ & $371.3 \pm 72.3$ & 399.6 \\
14 & $369.3 \pm 37.7$ & $366.3 \pm 49.4$ & $320.5 \pm 53.6$ & 352.1 \\
15 & $280.2 \pm 36.0$ & $283.1 \pm 41.4$ & $255.2 \pm 36.8$ & 272.8 \\
16 & $161.6 \pm 23.2$ & $166.1 \pm 38.6$ & $155.3 \pm 27.0$ & 161.0 \\
17 & $48.2 \pm 28.8$ & $45.4 \pm 28.6$ & $43.1 \pm 26.2$ & 45.6 \\
18 & $-29.5 \pm 20.4$ & $-32.5 \pm 21.1$ & $-30.5 \pm 19.9$ & -30.8 \\
19 & $-44.2 \pm 13.6$ & $-45.4 \pm 15.7$ & $-45.9 \pm 12.7$ & -45.2 \\
20 & $-39.6 \pm 13.3$ & $-41.6 \pm 14.2$ & $-42.3 \pm 11.6$ & -41.2 \\
21 & $-37.2 \pm 12.5$ & $-39.3 \pm 14.3$ & $-38.9 \pm 11.6$ & -38.5 \\
22 & $-34.3 \pm 12.0$ & $-35.7 \pm 14.6$ & $-36.2 \pm 11.1$ & -35.4 \\
23 & $-31.4 \pm 11.6$ & $-33.2 \pm 14.0$ & $-33.8 \pm 11.0$ & -32.8 \\
\hline
\end{tabular}

*Local time at Ile-Ife is GMT +1 .

were 120.7 and $123.1 \mathrm{Wm}^{-2}$, respectively. The surface radiative cooling was dominant during the dry months, November to March, with period average

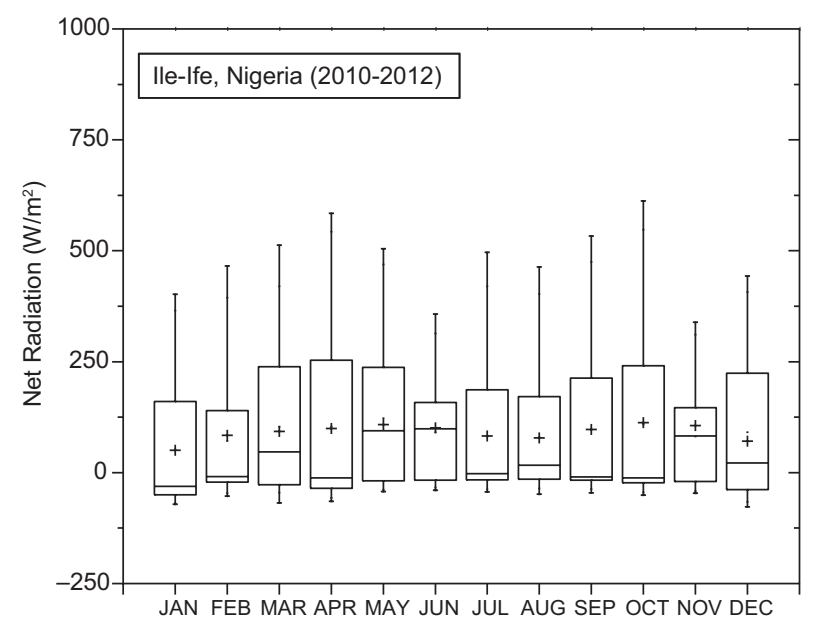

Fig. 5. Box and whisker plots of net radiation data at the OAU measurement site in Ile-Ife, Nigeria covering the observation period 2010-2012. values ranging between -13.5 and $-17.0 \mathrm{Wm}^{-2}$. Therefore, radiative heating at the surface was far in excess of the cooling for all months, which suggests

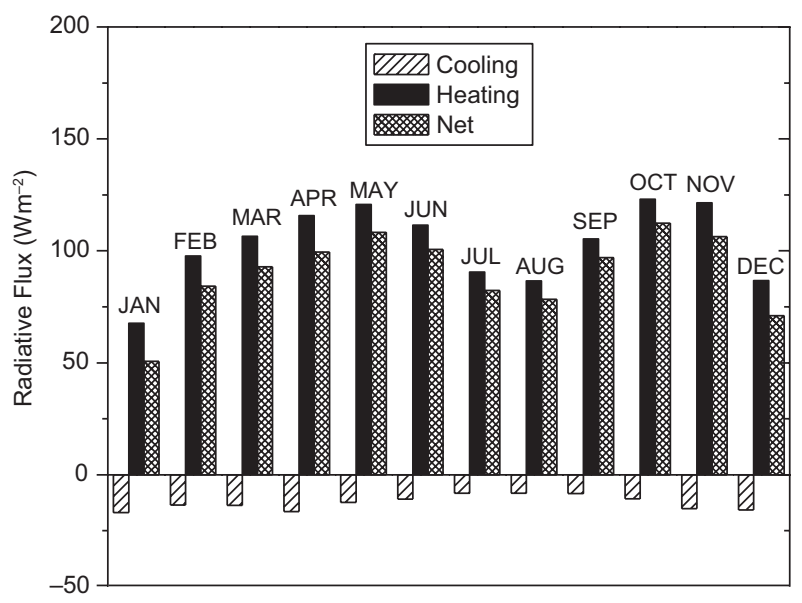

Fig. 6. Monthly means of net radiation at the measurement site in Ile-Ife, Nigeria (values indicate net radiative heating/cooling at the surface). 
an accumulation of radiative heat at the location. This feature can be linked to the intense solar radiation input at the surface that is common for tropical/ sub-tropical areas (Holton and Hakim, 2012). In IleIfe, the hourly maximum value of global radiation, $R_{S} \downarrow$ was higher than $1000 \mathrm{Wm}^{-2}$ (Balogun et al., 2003). In general, this study found a predominance of radiative heating at the surface for the location, with January showing the lowest value $\left(50.7 \mathrm{Wm}^{-2}\right)$ and May the highest $\left(108.3 \mathrm{Wm}^{-2}\right)$.

\section{Conclusions}

This study has established that the short-period $(<1$ hour) variability of hourly averaged values of net radiation is larger in the wet season than in the dry season, which is attributable to increased cloudiness and humidity, as well as a dynamically unstable atmosphere. The monthly mean values of net radiation showed both strong intra and inter-seasonal variations, and its annual trend follows a bimodal distribution. From hourly averaged data, radiative heating at the surface was found to be far in excess of radiative cooling, thus suggesting accumulation of heat (the daily budget indicated a net gain of radiative energy). To date, the net all-wave radiation data for Ile-Ife used in this study is almost certainly the most consistent and detailed data available for a tropical location in West Africa.

\section{Acknowledgements}

From 2004 to date, Nigeria Micrometeorological Experiments (NIMEX) have been supported by the following institutions: International Programmes in the Physical Sciences (IPPS); Uppsala University, Sweden; Alexander von Humboldt Foundation, Germany; and the University of Bayreuth (Prof. Dr. Thomas Foken, Department of Micrometeorology). Efforts by Mr. Jide Afolabi and other technical staff at the Department of Physics, Obafemi Awolowo University, Ile-Ife, in setting up the automated meteorological station is very much appreciated.

\section{References}

Adejokun J. A., 1966. The three-dimensional structure of the inter-tropical discontinuity over Nigeria. Nigerian Meteorological Service, Lagos, 9 pp.

Alados I., I. Foyo-Moreno, F. J. Olmo and L. Alados-Arboledas, 2003. Relationship between net radiation and solar radiation for semi-arid shrub-land. Agr. Forest Meteorol. 116, 221-227.
Amarakoon D. and A. Chen, 1999. Estimating daytime net radiation using routine meteorological data in Jamaica. Caribb. J. Sci. 35, 132-141.

Arnfied A. J., 1975. A note on the diurnal, latitudinal and seasonal variation of surface reflection coefficient. $J$. Appl. Meteorol. 14, 1603-1608.

Arya S. P., 1988. An introduction to micrometeorology. Academic Press, San Diego. 420 pp.

Augustine J. A. and E. G. Dutton, 2013. Variability of the surface radiation budget over the United States from 1996 through 2011 from high-quality measurements. J. Geophys. Res.-Atmos. 118, 43-53.

Balogun A. A., O. O. Jegede and J. O. Olaleye, 2003. Surface radiation budget over bare soil at Ile-Ife, Nigeria. Nigerian Journal of Solar Energy 14, 6-13.

Duchon C. E. and G. E. Wilk, 1994. Field comparison of direct and component measurements of net radiation under clear skies. J. Appl. Meteorol. 33, 245-251.

Foken T., 2008a. The energy balance closure problem - An overview. Ecol. Appl. 18, 1351-1367.

Foken T., 2008b. Micrometeorology. Springer-Verlag, Berlin, 320 pp.

Goutourbe J. P., T. Lebel, A. Tinga, P. Bessemoulin, J. Brouwer, A. J. Dolman, E. T. Engman, J. H. C. Gash, M. Hoepffner, P. Kabat, Y. H. Kerry, B. Monteny, S. Prince, F. Said, P. Sellers and J. S. Wallace, 1994. HAPEX-Sahel: A large-scale study of land-atmosphere interaction in the semi-arid tropics. Ann. Geophys 12, 53-64.

Griffiths J. F. (Ed.), 1974. World Survey of Climatology, vol. 10, Climates of Africa. Elsevier, Amsterdam, 620 pp.

Halldin S. and A. Lindroth, 1992. Errors in net radiometry: Comparison and evaluation of six radiometer designs. J. Atmos. Ocean. Technol. 9, 762-783.

Hayward D. F. and J. S. Oguntoyinbo, 1987. The climatology of West Africa. Rowan and Littlefield, New York, $271 \mathrm{pp}$.

Holton J. R. and G. J. Hakim, 2012. An introduction to dynamic meteorology, 5th ed. Academic Press, New York, $552 \mathrm{pp}$.

Iziomon M. G., H. Mayer and A. Matzarakis, 2000. Empirical models for estimating net radiative flux: A case study for three mid-latitude sites with orographic variability. Astrophys. Space Sci. 263, 313-330.

Jegede O. O., 1997a. Estimating net radiation from air temperature for diffusion modelling applications in a tropical area. Bound.-Lay. Meteorol. 85, 161-173.

Jegede O. O., 1997b. Diurnal variations of net radiation at a tropical station-Osu, Nigeria. Theor. Appl. Climatol. 58, 161-168. 
Jegede O. O., 1997c. Daily averages of net radiation measured at Osu, Nigeria. Int. J. Climatol. 17, 1357-1367.

Jegede O. O., 1998. A field study of the mean surface layer structure in sub-Saharan West Africa: The pre-monsoon (dry) season. Mausam 48, 361-370.

Jegede O. O., 2003. A note on net radiation at Osu, Nigeria. Meteorol. Z. 12, 269-271.

Jegede O. O., E. O. Ogolo and T. O., Aregbesola, 2006. Estimating net radiation using routine meteorological data at a tropical location in Nigeria. Int. J. Sust. Energy 25, 107-115.

Kothe S. and B. Ahrens, 2010. On the radiation budget in regional climate simulations for West Africa. $J$. Geophy. Res.-Atmos. 115, 1984-2012.

Matuszko D., 2012. Influence of the extent and genera of cloud cover on solar radiation intensity. Int. J. Climatol. 32, 2403-2414.
Matzinger N., M. Andretta, E. van Gorsel, R. Vogt, A. Ohmura and M. W. Rotach, 2003. Surface radiation budget in an Alpine valley. Q. J. Roy. Meteor. Soc. 129, 877-895.

Nielsen L. B., R. Berkowicz, K. Conradsen and L. P. Prahm, 1981. Net incoming radiation estimated from hourly global radiation and/or cloud observations. $J$. Climatol. 1, 255-272.

Ojo O., 1977. The climates of West Africa. Heinemann, London, $219 \mathrm{pp}$.

Smith G. L. and D. A. Rutan, 2003. The diurnal cycle of outgoing longwave radiation from earth radiation budget experiment measurements. J. Atmos. Sci. 60, 1529-1542.

Viudez-Mora A., 2011. Atmospheric downwelling longwave radiation at the surface during cloudless and overcast conditions: Measurements and modeling. Ph.D. thesis. Universitat de Girona, Spain. 